\title{
Effect Of Al3 + Inclusion on Characterization Exploration, Magnetic and Anti-Cancer Properties of Cobalt Ferrite Nanoparticles Synthesised by Co-Precipitation Process
}

\author{
S. Sobana, S. Alagumanian, R. Dinesh Kumar, P. Sakthivel, P. Sivakumar
}

\begin{abstract}
In current years cobalt ferrite $\left(\mathrm{CoFe}_{2} \mathrm{O}_{4}\right)$ nanoparticles are widely utilized in electronics and biomedicine. Undoped and Al doped cobalt ferrite nanoparticles were manufactured through cost operative co-precipitation process. $X$-ray diffraction analysis (XRD) showed single cubic phase of cobalt ferrite and a constant reduction of the lattice constant upon aluminum content. The scanning electron microscope (SEM) analysis acquired the uniform scale dispersion of the well crystallized grains. Optical band gaps $\left(E_{g}\right)$ were observed utilizing Transmittance spectra. Photo Luminescence (PL) studies displayed wide emission peak of energy $3.45 \mathrm{eV}$, credited to the charge recombination that is attributable to deep traps and lattice faults of confined surface states. Raman analysis proved the stretching of metal oxygen, active vibration of metal cation and bending vibrations. The vibrating sample magnetometry (VSM) analysis showed the coercivity $\left(H_{c}\right)$ and the saturation magnetization $\left(M_{s}\right)$ decline upon an rise in aluminum content. Cytotoxicity studies proved so as to the anticancer attributes of cobalt ferrite nanoparticles.
\end{abstract}

Keywords : MTT assay, Nanoparticles, Raman, SEM UV-vis, VSM, XRD

\section{INTRODUCTION}

In technology development,

synthesis and characterization of spinel ferrite nanoparticles are gaining attention on account of their outstanding magnetic, electrical attributes and different prospective utilization in a choice of fields [1-2]. Cobalt ferrite is a tough ceramic material utilized for transformer core and elevated frequency gadgets for their high resistivity to electricity and the property of high dielectric at room temperature [3]. Cobalt ferrite takes a regressive spinel edifice over $\mathrm{Co} 2+$ particles in octahedral (B) destinations and $\mathrm{Fe} 3+$ particles consistently scattered

Revised Manuscript Received on February 29, 2020.

* Correspondence Author

S. Sobana, Department of Physics, Periyar E. V. R. College, Tiruchirappalli, Tamil Nadu, India.Email - sobana1283@gmail.com

S. Alagumanian, Department of Botany, H.H.The Rajah's College, Pudukkottai, Tamil Nadu, India. Email - salagumanian@yahoo.co.in

R. Dinesh Kumar, Department of Mechanical Engineering, NIT Goa, India. Email: dineshrd453@gmail.com

P. Sakthivel, Department of Nanoscience and Technology, Alagappa University, Karaikudi - 630002, Tamil Nadu, India.

P. Sivakumar *, Department of Physics, Periyar E. V. R. College, Tiruchirappalli, Tamil Nadu, India

(C) The Authors. Published by Blue Eyes Intelligence Engineering and Sciences Publication (BEIESP). This is an open access article under the CC BY-NC-ND license (http://creativecommons.org/licenses/by-nc-nd/4.0/) connecting tetrahedral (A) and octahedral (B) locales. The properties of nano ferrites are slightly altered by replacement of numerous metal cations [4-5].

Attributes of the cobalt ferrite tinny film could be changed by doping of double and triple valency ions in addition to altering the parameters used for synthesis such as substrate temperature, annealing temperature, distance, $\mathrm{pH}$ and grain size among the substrate towards nozzle [6-7]. The decrease in magnitude of ferrite nano material crystallite generate the changes of neel temperature, peak value of coercivity along with improved magnetization [8]. Annealing temperature impacts on the prompt increase of the particle size of ferrite materials $[9,10]$. The $21^{\text {st }}$ century is the golden era for nanotechnology owing to its wider applications in biological sciences, industry, agriculture, medicine, and pharmaceutics. Ferrite nanoparticles are highly preferred for their super paramagnetic utilization and surface area to volume ratio beyond metal and metal oxide nanoparticles, that are totally diverse with its mass counterparts [11,12]. Based on crystal structure and magnetic properties, ferrites shall remain hexaferrite/orthoferrite, spinel, garnet in which spinel structures of the modified metal ferrite nanoparticles are specific in its prominent catalytic, increased adsorption, magnetic , optical and electronic attributes [13,14]. Due to its high penetrability and efficient dispersion magnetization, ferrite nanoparticles are magnetically soft. Ferrite nanoparticles could be changed by tuning the magnitude, form and quantity of substituted ions $\left(\mathrm{Mn}^{2+}, \mathrm{Fe}^{2+}, \mathrm{Ni}^{2+}, \mathrm{Co}^{2+}\right.$, etc.), and their spinel ferrite NPs have been employed in biomedicine intended for recognising cancer cells and investigating dopamine. Magnetic hyperthermia for tumor treatment, drug delivery, cellular signalling, magnetic resonance imaging, magnetic recording, catalysis sensing and in water and wastewater treatment $[15,16]$. Synthesis of Spinel ferrite nanoparticles are carried out by various techniques like polymeric precursor, microemulsions, sonochemical, ball milling, auto combustion, solvothermal, hydro-thermal, reverse micelles, sol-gel, coprecipitation, aerosol spray pyrolysis, and biogenic method using bacteria Geobacter sulfurreducens. [17] Cobalt ferrites contain great magnetic anisotropy collective through an eminent assessment of saturation magnetization. Impressive anisotropy permits them to reside magnetized in excess intermissions of time during deficiency of magnetic field. Cobalt ferrite is introduced as potential drug in biomedical trade in tumor treatment using hyperthermia. 
Large quantity of energy lost during magnetization is due to high coercivity. The energy creates magnetic heating during cancer cell therapy. [18-20]. Currently, investigators have researched to upgrade properties namely magnetic and electrical in cobalt ferrite nanoparticles to improve memory storage in gadget, high frequency gadget function by doping with two and three valency metal ions [21-23]. The available literatures on this ferrite NPs are only the description of spinel ferrite thin film [24-25]. In current times, Bhujun et al [26] doped trivalent metal ions $\mathrm{Al}^{3+}$ in $(\mathrm{Ni}-\mathrm{Cu})$ ferrite nanomaterials and produced aluminium-doped nickel copper ferrite nanomaterials with enhanced electrochemical properties. Maksoud et al. [27] have recorded dye (methylene blue) degradation, antibacterial and anti-biofilm activities in metal ( $\mathrm{Zn}, \mathrm{Cu}, \mathrm{Mn}$ ) substituted ferrite nanoparticles.

So far, there is no literature on the $\mathrm{Al}^{3+}$ doped cobalt ferrite nanoparticles fabrication using co-precipitation process. The present work focused on the cobalt ferrite models doped with $\mathrm{Al}^{3+}$ ions in different proportion. The model could also be expressed using the generic formula $\mathrm{CoAl}_{\mathrm{x}} \mathrm{Fe}_{2-\mathrm{x}} \mathrm{O}_{4}$ with ' $\mathrm{x}$ ' represent $0.0,0.2,0.4,0.6,0.8$ and 1.0. Chemical co-precipitation method was adopted to produced uniform and unique particle size and phase purity. The architectural description was not engaged for utilizing X-ray diffraction, SEM, UV, Photoluminescence, Raman spectroscopy and transmission electron microscopy. Cell viability was measured using MTT assay.

\section{EXPERIMENTAL DETAILS}

\section{Preparation of Hygrophila auriculata extract}

Extensive study is done utilizing plants and their parts for nanoparticle mixture as a result of its straightforwardness in scaling up for increased creations separated from being economically sense and eco friendly. Hygrophila auriculata (K. Schum) Heine (Family: Acanthaceae) is a part of a helpful medicinal plants generally known as the "Marsh Barbel". Various conventional healers have asserted the sufficiency of Hygrophila auriculata in light of the fact that an alternate of obsessive conditions like a diuretic, choleretic and bug spray well beyond in routine solution for hacks, colds, agonizing swellings and critically used for cancer treatment. Componenets made confined as of the roots of Hygrophila auriculata, containing a water-dissolvable, naturally active complex that records for 40-50 percent of complete dry material weight. Thus composite is made up of flavonoids, triterpene, saponin, pectins, mineral salts, simple sugars, polysaccharides, amino acids, essential oil resins,, fat, protein, sterols, volatile oils, starches (30\%), tannins, glycosides, and dissimilar substances [28]. At first, Hygrophila auriculata roots were gathered and washed by refined water and dried at $40^{\circ} \mathrm{C}$ for one day in oven. The powder passed 100 mesh sieves and stored on a desiccators.

\section{Preparation of Aluminium-substituted cobalt nano-ferrites}

Al doped cobalt ferrite models were produced by the formula (i.e) CoAlxFe2-xO4 (0.0, $0.2,0.4,0.6,0.8 \& 1.0)$ by chemical co-precipitation process. Stoichiometric quantity of $\mathrm{Co}\left(\mathrm{NO}_{3}\right) 2.6 \mathrm{H}_{2} \mathrm{O}, \mathrm{Al}\left(\mathrm{NO}_{3}\right) 2.9 \mathrm{H}_{2} \mathrm{O}, \mathrm{FeCl}_{3}$ were mixed with de-ionized water further it is stirred over a magnetic plate. The extract of Hygrophila auriculata was then added in drops to obtain clear solution by dynamic mixing on solution prepared maintained at room temperature. As far as the above arrangement, $\mathrm{NaOH}$ was gradually included drop insightful till the $\mathrm{pH}$ value of the solution reaches 7 . Subsequently, solution's pH value was increased to 10 and further the solution was processed at the temperature of 800 ${ }^{\circ} \mathrm{C}$ for two hours with constant mixing to assurance maximum reaction occurrence. The solution was refrigerated and sluiced with demineralised water continuously for attaining the $\mathrm{pH}$ value of 7 . The extra hydroxyl ions were removes, the solution was rinsed with ethanol, and allowed to dry. After drying, the models were sintered for 3 hours at $1100{ }^{\circ} \mathrm{C}$ and ground to get fine black powder. The black powder obtained was used for entire characterizations.

\section{Characterizations}

For research purpose electrical, magnetic, structural, optical, and surface morphology properties of $\mathrm{Al} 3+$ doped cobalt ferrite nanoparticles produced uses various characterization strategies. The core portrayal of the model was not engaged for X-ray diffractometry using a $\mathrm{Cu}$ target containing a characteristic wavelength $1.5406 \mathrm{~A}^{\circ}$ of $\mathrm{Cu}-\mathrm{K} \alpha$. The scanning was done at the angle between $20^{\circ}$ to $80^{\circ}$ at $0.02^{\circ}$ scanning per second. The TEM images were captured by JEOL electron microscope. Raman spectra have been approved through STR-500 taken at room temperature. UV spectrometer with wavelength range of $200-800 \mathrm{~nm}$ in was used to measure optical absorption. The surface profiler was used for measuring thickness of thin film Al doped nickel ferrite. The hysteresis and the M-T measurements were not engaged for utilizing a SQUID magnetometer (Quantum Design). The models are designated as Al 0.0, 0.2, 0.4, 0.6, 0.8 and 1.0 based on the dopant (Al) concentration.

\section{Cell viability assay of Nanoparticles}

The 5-diphenyltetrazolium bromide (MTT), 3-(4, 5-dimethylthiazol-2-yl)-2 assay technique was used to examine the cytotoxicity of CoAlxFe2-xO4 (0.0, 0.2, 0.4, 0.6, 0.8 and 1.0) nanoparticles [29,30]. Firstly, L 929 fibroblast cell lines there seeded on a consistency in 96-well plates with 1104 cells and hatched for 24 hours duration . At the subsequent stage, $50 \mathrm{ml}$ of nanoparticles $(62.5$, 125 , 250 and $500 \mathrm{mg} / \mathrm{ml}$ was included to respectively well. The further hatching is done for $48 \mathrm{~h}, 20 \mathrm{ml}$ of $5 \mathrm{mg} / \mathrm{ml}$ was introduced for all well and further cells were hatched at $37^{\circ} \mathrm{C}$ for duration of 3 hours. The formazan crystal generated by live cells were removed by adding $100 \mathrm{ml}$ of DMSO. Using spectrophotometer at $570 \mathrm{~nm}$ Optical absorbance was calculated and cell feasibility was determined based on the usual experiment. During the process of cell culture, L 929 fibroblast cell lines grown in RPMI promotes $10 \%$ of FBS, penicillin of $100 \mathrm{U} / \mathrm{ml}$ and streptomycin of $100 \mathrm{mg} / \mathrm{ml}$. The cells were hatched at the temperature of $37{ }^{\circ} \mathrm{C}$ in $5 \%$ humidified $\mathrm{CO}_{2}$ 


\section{RESULTS AND DISCUSSION}

Structural analysis

The XRD of $\mathrm{CoAl}_{\mathrm{x}} \mathrm{Fe}_{2-\mathrm{x}} \mathrm{O}_{4}(\mathrm{x}=0.2,0.4,0.6,0.8 \& 1)$ ferrites nanoparticles set up by chemical co-precipitation method shown in Figure 1. The Cobalt ferrites $\left(\mathrm{CoFe}_{2} \mathrm{O}_{4}\right)$ XRD pattern related about reference data through the JCPDS. The reflecting planes (200), (311), (400), (422), (511), (440) obtained through XRD pattern of nanoparticles authorizes the development of single-phase cubic spine structure. Based on the XRD spectrum it is acquired such the entire models shows single-phase structure. Models don't describe any impurity peaks. The average crystalline size (D) was considered utilizing Debye Scherer's formula (1)

$$
D=\frac{(0.9 \lambda)}{\beta \cos \theta}
$$

Where,

\section{$\theta \sim$ Bragg's angle}

\section{$\beta \sim$ full width half maximum(FWHM)}

For cubic spinel structural model, lattice parameter was computed for utilizing the formula (2)

$$
d=a / \sqrt{h^{2}+k^{2}+l^{2}}
$$

Where,

$$
\begin{aligned}
& d \sim \text { inter planner spacing } \\
& (h, k, l) \sim M i l l e r \text { Indices } \\
& a \sim \text { lattice parameters }
\end{aligned}
$$

The calculation of Cell volume (V) is done by

$$
V=a^{3}
$$

With reference to Table 1 it is clear that increase in $\mathrm{Al}$ powder decrease lattice constant (a) by on account of the variance in ionic radius between $(0.50 \AA-0.64 \AA)$ for $\mathrm{Al}^{3+}$ and $\mathrm{Fe}^{3+}$ ions.

$\mathrm{X}$-ray density was calculated by equation [3, 4]:

$$
\mathrm{P}_{\mathrm{x}}=8 \mathrm{M} / \mathrm{Na}^{\mathrm{s}}
$$

Where,

$$
\begin{aligned}
& M \sim \text { relative molecular weight, } \\
& N \approx \text { Avagadro Number } \\
& A \approx \text { lattice constant }
\end{aligned}
$$

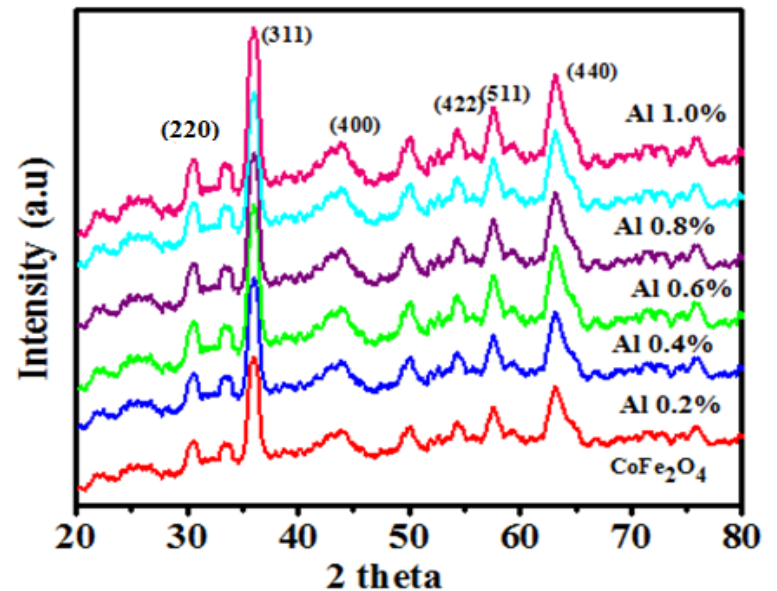

Figure $1 . X$ - ray diffraction pattern of (i)pure,(ii) $0.2 \%$,(iii) $0.4 \%$, (iv) $0.6 \%$, (v) $0.8 \%$ and (vi) $1.0 \%$ Al doped Co-ferrite samples
X-ray density reduced with $\mathrm{Al}$ substitution also it was ascribed in consequence of decrease in particle size and lattice constant. Same conclusion have acquired by Bugad et al. [31] and Suryawanshi et al. [32]. This kind of phenomenon was attributed as a reason of the comparative reduction in molecular weight is over and above the slight weakening of lattice parameter. Table 1 display that the lattice constant, average particle size, X-ray density and cell volume.

Table 1 . $\mathrm{CoAl}_{\mathrm{x}} \mathrm{Fe}_{2-\mathrm{x}} \mathrm{O}_{4}$.Structural parameters

\begin{tabular}{|l|l|l|l|l|}
\hline $\begin{array}{l}\text { Compound } \\
(\mathbf{x}) \text { (Al) }\end{array}$ & $\begin{array}{l}\text { Lattice } \\
\text { constant(a) } \\
\mathbf{( A )}^{\circ}\end{array}$ & $\begin{array}{l}\text { Average } \\
\text { Particle } \\
\text { size(D) } \\
\mathbf{N m}\end{array}$ & $\begin{array}{l}\text { Cell } \\
\text { Volume } \\
(\mathbf{A})^{3}\end{array}$ & $\begin{array}{l}\text { X-Ray } \\
\text { Density } \\
(\mathbf{D x}) \\
\mathbf{g m} / \mathbf{c m}^{3}\end{array}$ \\
\hline 0 & 8.3314 & 42 & 578.301 & 5.2845 \\
\hline 0.2 & 8.3324 & 40 & 576.428 & 5.1254 \\
\hline 0.4 & 8.3105 & 39 & 573.959 & 5.0224 \\
\hline 0.6 & 8.3012 & 37 & 572.035 & 4.9583 \\
\hline 0.8 & 8.2881 & 35 & 569.331 & 4.8498 \\
\hline 1 & 8.2531 & 34 & 562.148 & 4.8120 \\
\hline
\end{tabular}

Scanning Electron Microscope

SEM micrographs of $\mathrm{CoAl}_{x} \mathrm{Fe}_{2-x} \mathrm{O}_{4}(x=0,0.2,0.4$, 0.6, $0.8 \& 1$ ) nanoparticle models used to be demonstrated in Fig -2, which were set up by chemical co-precipitation process. Fine crystalline grains with uniform magnitude of $\mathrm{CoAl} \mathrm{Fe}_{2-x} \mathrm{O}_{4}$ were founded. The average grain size of $\mathrm{CoFe}_{2} \mathrm{O}_{4}$ and $\mathrm{CoAl}_{x} \mathrm{Fe}_{2-x} \mathrm{O}_{4}$ were found to be $136.5 \mathrm{~mm}$ and $130.5 \mathrm{~mm}$ correspondingly. The increase in aluminium addition decreases average grain size and it is validated by XRD pattern. The average grain size was over and above a nanoparticle $(100 \mathrm{~nm})$. Comparable behavior used to be acquired for Nano-sized $\mathrm{NiAl}_{\mathrm{x}} \mathrm{Fe}_{2} \mathrm{O}_{4}$ powder [33-34]. Earlier Jamil et al 2017 [35] recorded the average grain size reduced when $\mathrm{Zn}$ - addition was increased in cobalt ferrite $\left(\mathrm{CoFe}_{2} \mathrm{O}_{4}\right)$ nanoparticles.

Optical properties

The Al substituted Co ferrites UV-visible transmittance spectra is shown in Fig.3, the transmittance is propositional to the doping of Al. In Fig. $3 \mathrm{x}=0$ displays black colour where the transmittance is observed to be very low but the absorption is maximum at $x=1$. On behalf of other five diverse concentrations such as (at $\mathrm{x}=$ $0.2,0.4,0.6,0.8 \& 1$ ) transmittance is very close mutually but it reaches maximum at lower wavelength. But the wide-ranging movement as every six curves illustrates the similar behavior. The optical absorption spectra of $\mathrm{CoFe}_{2} \mathrm{O}_{4}$ and doped with $\mathrm{Al}$ nanoparticles in addition to their comparison plot of ( $\alpha h v)^{2}$ to photon energy ( $h v$ ) manufactured co-precipitation method is exposed in Fig.4.

\section{by}

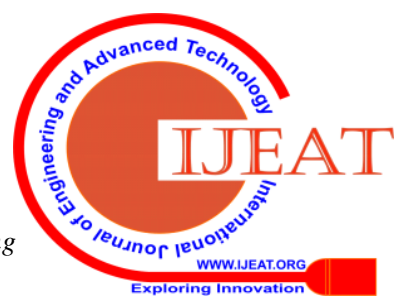


In the direct transition, the absorption coefficient $(\alpha)$ relates over the optical band

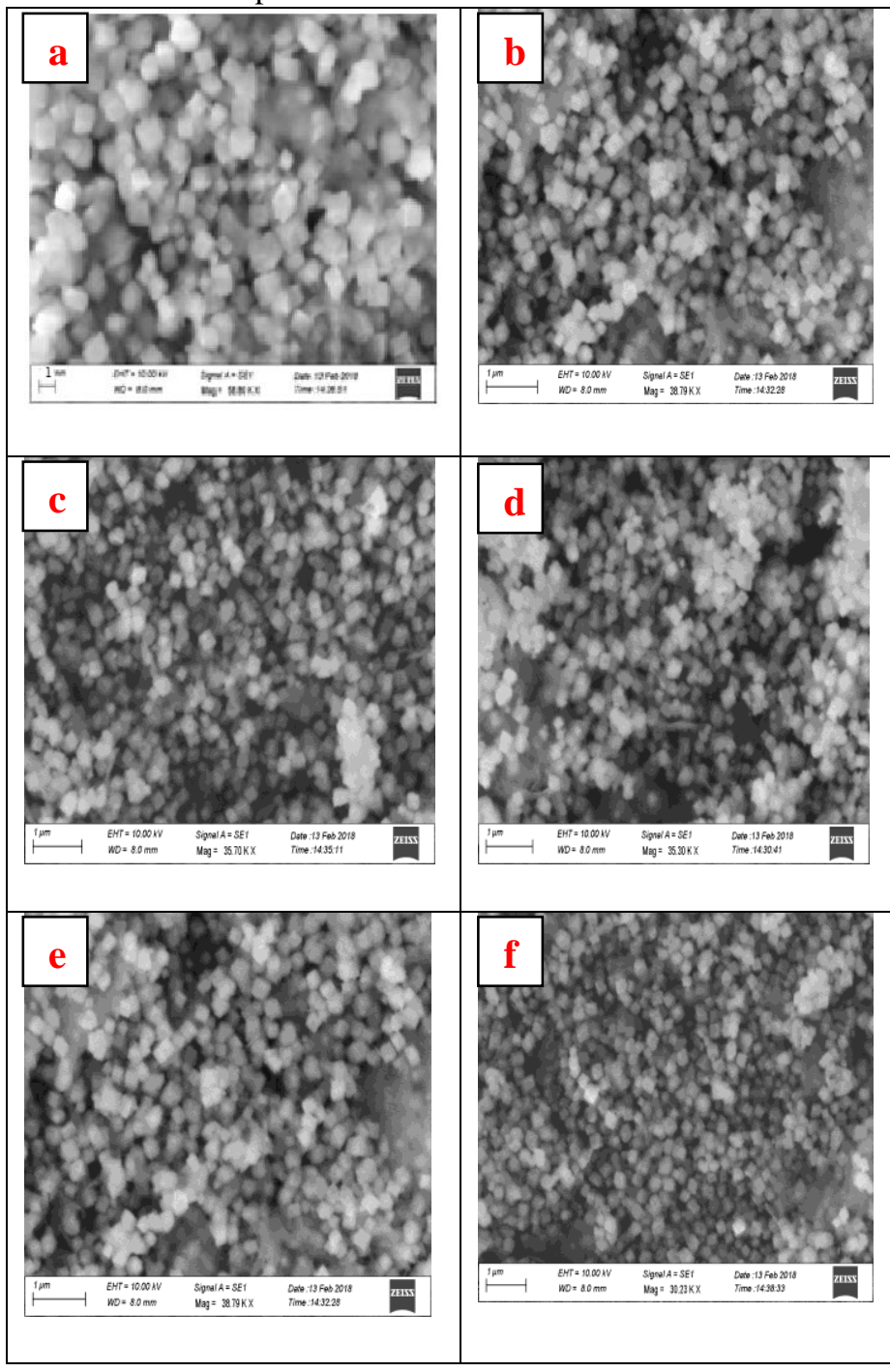

Figure 2 . SEM microimage with (a)0\%,(b)0.2\%, (c)0.4\%,(d)0.6\%,(e)0.8\%,(f)1\%) Al doped samples.

gap (Eg) is given by,

$\alpha h v=B(h v-E g)^{1 / 2}$

Where,

$h v \approx$ photon energy,

$B \sim$ steady direct transition

The energy gap Eg can be evaluated upon the interrupt of hv to that of direct transitions. Through extrapolation for linear part of the energy axis at zero absorption provides the direct band gap of those materials. The model manufactured by co-precipitation method is absorption edge with red shift associated as far as immensity band gap. $\mathrm{Al}^{3+}$ ions addition decreases energy band gap in cobalt ferrite nanoparticles.

The contraction in band bap in the recent situation is due to as increase on the crystallization and decreasing the crystalline defects which means decreasing the number of energy levels among conduction band and valence band in addition to reduce in lattice constant upon $\mathrm{Al}$ concentration [36,37].Fig 4 shows the effect optical energy band gap due to hike in $\mathrm{Al}^{3+}$ concentration.

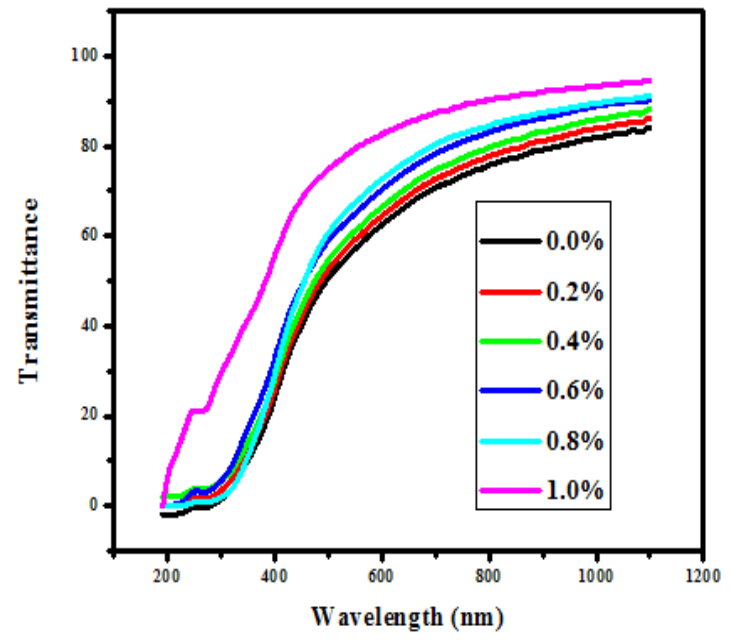

Figure 3 . UV Transmittance spectra for $\mathrm{Al}_{\mathrm{x}} \mathrm{CoFe}_{2-\mathrm{x}} \mathrm{O}_{4}$ with $\mathrm{x}=0.0,0.2,0.4,0.6,0.8$ and $1.0 \%$

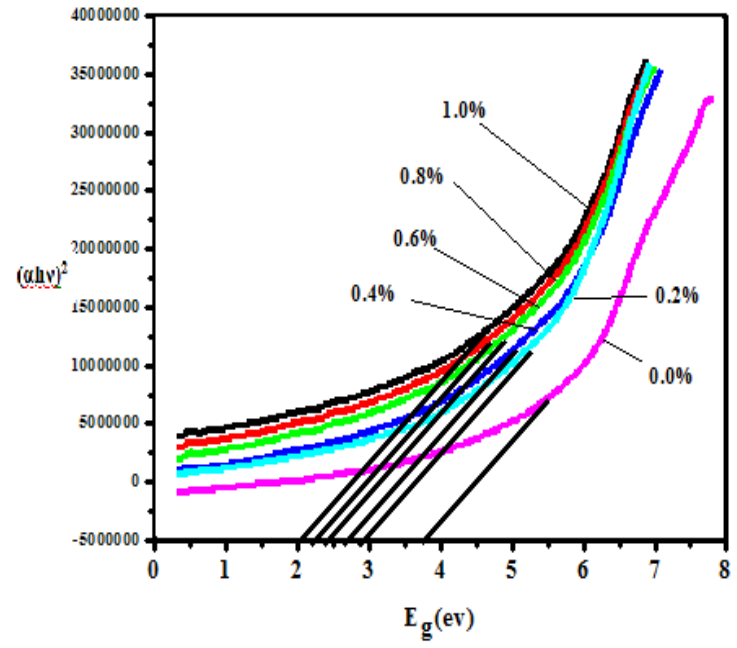

Figure 4 . $(\alpha h v) 2$ Vs Photon energy (eV) plot

Photoluminescence spectra $(P L)$

PL spectroscopy is the outstanding method to gain constructive knowledge is combined with energy in addition to motion of charge carriers formed within the revelation of light. This spectra of spinel ferrite nanoparticles produces knowledge in the energies and movement of image created charge taken, including the behaviour of the discharging states. An electron from ferrite models is located in the states such as trap, excitonic and conduction band [38-40]. It is very much perceived that made and skill is amazingly receptive to landscape of nanoparticles surface, owing to event of opening surface conditions have expanded from surface non-stoichiometry and unsaturated bonds. Augment luminescence skills and non-radioactive recombination were allowed by Surface trap states . [41]. Photoluminescence (PL) spectrum of $\mathrm{CoAl}_{\mathrm{x}} \mathrm{Fe}_{2-\mathrm{x}} \mathrm{O}_{4}$ ferrite at a variety of attentiveness of $\mathrm{Al}$ doped is made in Fig. 5. The broad emission peak with energy $3.45 \mathrm{eV}$ is defined in the pattern spectrum to the recombination of the charge suitable for lattice defects and deep traps of confined surface conditions [42]. Such impacts are the cause of luminescent properties in the nanomaterial lattice. 
Additionally, photoluminescence (PL) peak is allocated to rebind the load in deep traps of localized surface conditions and lattice defects [43-44]. Consequently, such defects are accountable to the manufactured nanomaterials for the luminescent attributes. In this method, the spectral position and output of crystallite fluorescence could be tailored by altering the colloid surface's chemical nature. Hence it has proved with the intention of the elevated wavelength peak may come by reason of several impurities in our material. The presence of nanoparticular defects was also suggested through the pattern's SEM images (Fig.2).

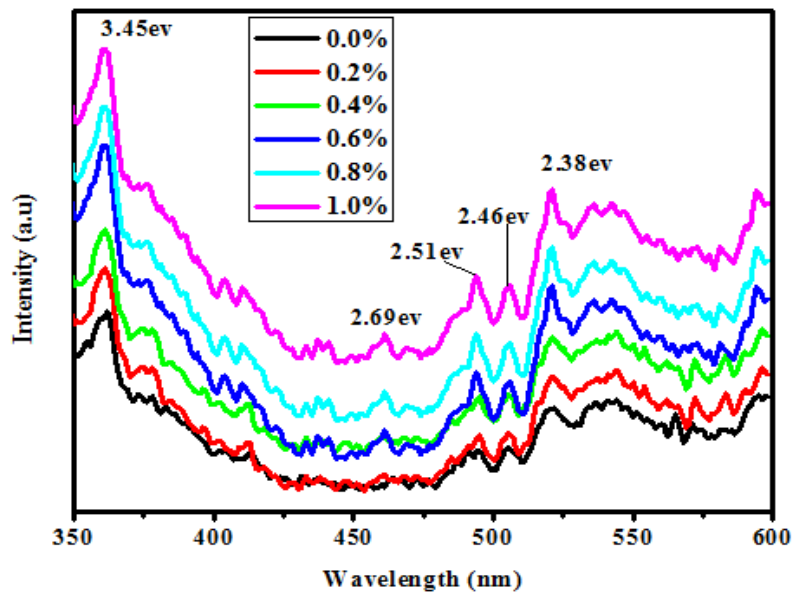

Figure 5 . Photoluminescence (PL) spectra of the denoted model $\mathrm{CoAl}_{x} \mathrm{Fe}_{2-\mathrm{x}} \mathrm{O}_{4}$ with $\mathrm{x}=0.0,0.2,0.4,0.6,0.8$ and $1.0 \%$.

\section{Raman spectroscopy}

This testing is used to analyse the purity and structure of cobalt ferrite nanoparticles doped by $\mathrm{Al}^{3+}$. The Figure 6 displays the Raman spectra of $\mathrm{CoAlxFe2-xO4}$ undoped and $\mathrm{Al}^{3+}$ doped. The $3 \mathrm{~F}_{2 \mathrm{~g}}$, one $\mathrm{A}_{1 \mathrm{~g}}$, one $\mathrm{E}_{\mathrm{g}}$ modes were the high intensive Raman modes of cobalt ferrite [45]. Raman peaks in excess of the region of $565-735 \mathrm{~cm}^{-1}$ stand for the octahedral-site vibrational modes and those in the 1119-1364 $\mathrm{cm}^{-1}$ area refers to the tetrahedral-site of ferrites vibrational modes [46]. In the present research model, $642 \mathrm{~cm}^{-1}$ represent the Raman shift vibrational mode originated in tetrahedral site of metal oxide bond. [47]. The lack of impurity in cobalt ferrite nanoparticles doped by $\mathrm{Al}^{3+}$ is confirmed by Raman spectra.

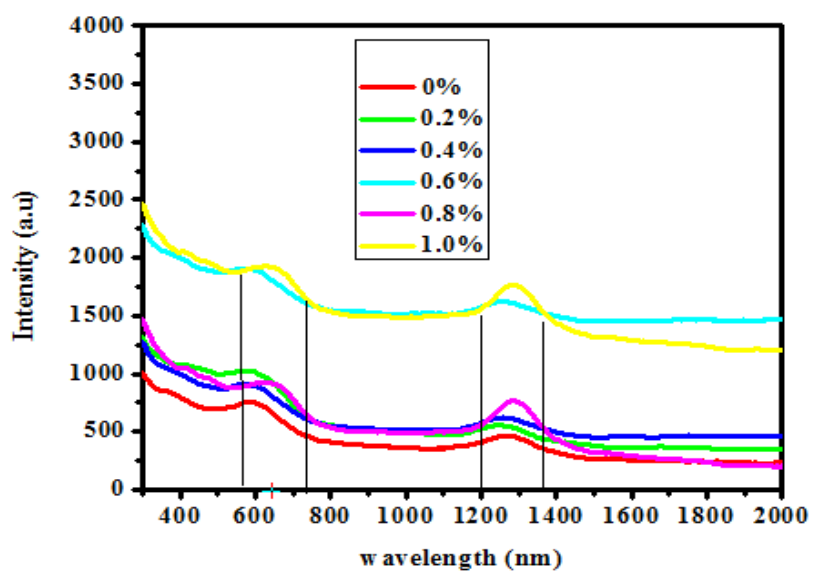

Figure 6 . Raman spectra of $\mathrm{CoAl}_{x} \mathrm{Fe}_{2-\mathrm{x}} \mathrm{O}_{4}(0.0-1.0)$ nanoparticles.

\section{Magnetic Properties}

The Figure 7 reveals hysteresis loops formed by applied field for $\mathrm{Al}^{3+}$ doped nanoparticles. Table 2 gives the significant magnetic information like saturation magnetisation $\left(\mathrm{M}_{\mathrm{s}}\right)$, remanence magnetisation $\left(\mathrm{M}_{\mathrm{r}}\right)$, squareness ratio $\left(\mathrm{M}_{\mathrm{r}} / \mathrm{M}_{\mathrm{s}}\right)$, and coercivity $\left(\mathrm{H}_{\mathrm{c}}\right)$. From figure and table it is evident that the concentration of $\mathrm{Al}_{3}{ }^{+}$decreases both saturation magnetisation and coercivity this reduction is coupled with grain size reduction [48]. Following the increase of aluminium ion leads to decrease in magnetisation could brief the reason of cation sharing among octahedral(B) and tetrahedral(A) sites. The non-magnetic $\mathrm{Al}^{3+}$ ions exchanges $\mathrm{Fe}^{3+}$ and takes up the octahedral position instead of tetrahedral . Pertaining phenomenon disables the meeting of $\mathrm{AB}$ interface as $\mathrm{Al}^{3+}$ ion in taking up fraction share becau.se of non magnetic nature. Therefore the increase of $\mathrm{Al}^{3+}$ content decreases the saturation magnetization. [49,50]. With increase in the concentration of $\mathrm{Al}^{3+}$ ion Coercivity decreases. It might be as a result of decrease in anisotropy field and reduces field wall energy [51].

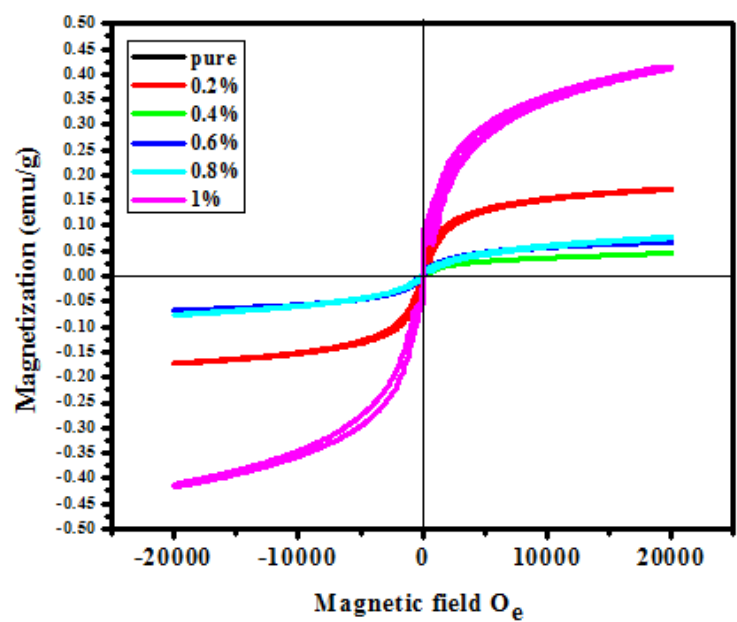

Figure 7 . M-H loop of $\mathrm{Al}_{x} \mathrm{CoFe}_{2-x} \mathrm{O}_{4}(0.0-1.0)$ nanoparticles.

\begin{tabular}{|l|l|l|l|l|l|}
\hline $\begin{array}{l}\text { S. } \\
\text { No }\end{array}$ & $\begin{array}{l}\text { Al } \\
\text { content } \\
(\mathrm{x})\end{array}$ & $\begin{array}{l}\text { Remancance } \\
\text { Magnetisation } \\
\mathrm{Mr} \\
(\mathrm{emu} / \mathrm{g})\end{array}$ & $\begin{array}{l}\text { Saturation } \\
\text { Magnetisation } \\
\text { Ms } \\
(\mathrm{emu} / \mathrm{g})\end{array}$ & $\begin{array}{l}\text { Squareness } \\
\text { Ration } \\
\mathrm{Mr} / \mathrm{Ms}\end{array}$ & $\begin{array}{l}\text { Coercivity } \\
\text { Hc } \\
\text { [Oe] }\end{array}$ \\
\hline 1 & 0.0 & 0.76392 & 1.11373 & 0.4129 & 561.40 \\
\hline 2 & 0.2 & 0.64183 & 1.02391 & 0.3965 & 557.21 \\
\hline 3 & 0.4 & 0.48341 & 0.95634 & 0.3736 & 553.73 \\
\hline 4 & 0.6 & 0.31481 & 0.85402 & 0.3686 & 549.57 \\
\hline 5 & 0.8 & 0.24813 & 0.63183 & 0.3425 & 546.29 \\
\hline 6 & 1.0 & 0.15284 & 0.4740 & 0.2958 & 542.65 \\
\hline
\end{tabular}

\section{Cytotoxicity and alteration in cell morphology}

The DLA cell lines and L929 cell line will be considered for viability by utilizing MTT assays (Table-3, 4).

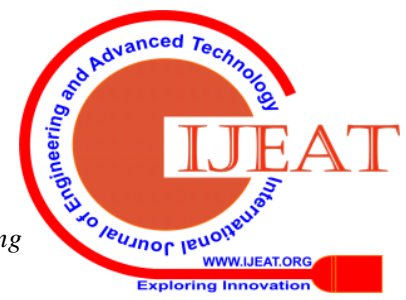


Effect Of Al3 + Inclusion on Characterization Exploration, Magnetic and Anti-Cancer Properties of Cobalt Ferrite Nanoparticles Synthesised by Co-Precipitation Process

This was obtained by the fact that incubation with CoAlxFe2-xO4 (0.0 -1.0) NPs induced a small decrease in cell viability. After incubation with magnetic NPs, cell viability was about 95 per cent up to $500 \mu \mathrm{g} \mathrm{ml} \mathrm{ml}^{-1}$. $\mathrm{CoAl}_{0.2} \mathrm{Fe}_{1.8} \mathrm{O}_{4}$ NPs has significant effect for feasibility of L929 cells. In each model the occurrence of dopants in a higher quantity also makes cytotoxicity as the quantity of dopants must be optimized. This result is assisted by earlier procedure conclusion wherein the $\mathrm{CoFe}_{2} \mathrm{O}_{4}$ NPs displayed toxicity just at high concentrations [52,53]. As stated in the existing Trojan horse theory for metal NPs, metal ions dropped with the NPs can insert the fibroblast cells and create cytotoxicity [54]. The live, necrotic and apoptotic cells are put together after the incubation period, which could result in the danger of dose-dependent CoFe2O4 NPs and could be limited by proper dose control of NPs. These impacts of cobalt ferrite assimilation may be due to a dramatic inhibition of transcriptional regulation and protein mixture, resulting in cell phenotype loss and likely cell death [55]. In the control model (zero concentration), not even different groups were important; while the cell viability of CoAl0.2Fe1.8O4 showed a statistically significant difference in similarity to other groups ( $\mathrm{P}$-value $<0.001)$ shown in fig-8 by increasing Al concentration. Figure 9 (a-f) displays the images of L929 cells in contact with CoAl0.2Fe1.8O4 NPs. As explained by the figure, no important coherence was seen at the model also the cells were same for control the sample, thus in front of CoAl0.2Fe1.8O4, NPs cells contain little toxicity, also it provides that this model may be the optimum option for biomedical utilization. Such results are consistent with previously obtained action on dermal fibroblasts, that introduced the nanoparticles of gold / citrate inhibited the explosion of dermal fibroblasts and induced an irregular composition of actin filaments, resulting in decreased cellular motility and cell morphology impact.[56]. The smaller particle of Citrated and biotinylated gold particles are more toxic than $18 \mathrm{~nm}$ gold nanoparticles, in leukemic cells. [57]

Table 3 . Percentage of cytotoxicity of $\mathrm{CoAl}_{x} \mathrm{Fe}_{2-\mathrm{x}} \mathrm{O}_{4}(\mathrm{x}$ $=0,0.2,0.4,0.6,0.8 \& 1$ ) nanoparticle samples (DLA Cells)

\begin{tabular}{|c|c|c|c|c|}
\hline $\begin{array}{l}\text { Nano } \\
\text { particles } \\
(\%)\end{array}$ & $\begin{array}{l}\text { Vol of } \\
\text { Cells } \\
(\boldsymbol{\mu L})\end{array}$ & $\begin{array}{l}\text { No of } \\
\text { Viable } \\
\text { Cells }\end{array}$ & $\begin{array}{l}\text { No of } \\
\text { Dead } \\
\text { Cells }\end{array}$ & $\begin{array}{l}\text { \% } \\
\text { Cytotoxiciy }\end{array}$ \\
\hline 0 & 100 & 100 & 0 & 0 \\
\hline $1.0 \%$ & 100 & 0 & 100 & 100 \\
\hline $0.8 \%$ & 100 & 0 & 100 & 100 \\
\hline $0.6 \%$ & 100 & 14 & 86 & 86 \\
\hline $0.4 \%$ & 100 & 94 & 6 & 6 \\
\hline $0.2 \%$ & 100 & 99 & 1 & 1 \\
\hline
\end{tabular}

Table 4 . Percentage of cytotoxicity of $\mathrm{CoAl}_{x} \mathrm{Fe}_{2-\mathrm{x}} \mathrm{O}_{4}(\mathrm{x}=\mathbf{0 , 0 . 2 , 0 . 4 , 0 . 6 , 0 . 8} \&$ \& $)$ nanoparticle samples (MTT L929)

\begin{tabular}{|c|c|c|c|c|c|c|}
\hline MTT L929 & \multicolumn{6}{|c|}{$\mathrm{CoAl}_{x} \mathrm{Fe}_{2-\mathrm{x}} \mathrm{O}_{4}(\mathrm{x}=0,0.2,0.4,0.6,0.8$ and 1$)$} \\
\hline Volume of sample & OD-1 & OD-2 & OD-3 & OD-4 & Average & \%cyto toxicity \\
\hline $0 \%$ & 0.236 & 0.243 & 0.238 & 0.239 & 0.239 & 0 \\
\hline $1 \%$ & 0.183 & 0.186 & 0.18 & 0.236 & 0.181 & 24.16 \\
\hline $0.80 \%$ & 0.214 & 0.217 & 0.219 & 0.237 & 0.209 & 12.55 \\
\hline $0.60 \%$ & 0.228 & 0.229 & 0.23 & 0.237 & 0.23 & 3.66 \\
\hline $0.40 \%$ & 0.239 & 0.241 & 0.238 & 0.238 & 0.239 & 0.21 \\
\hline $0.20 \%$ & 0.236 & 0.239 & 0.24 & 0.239 & 0.239 & 0 \\
\hline
\end{tabular}

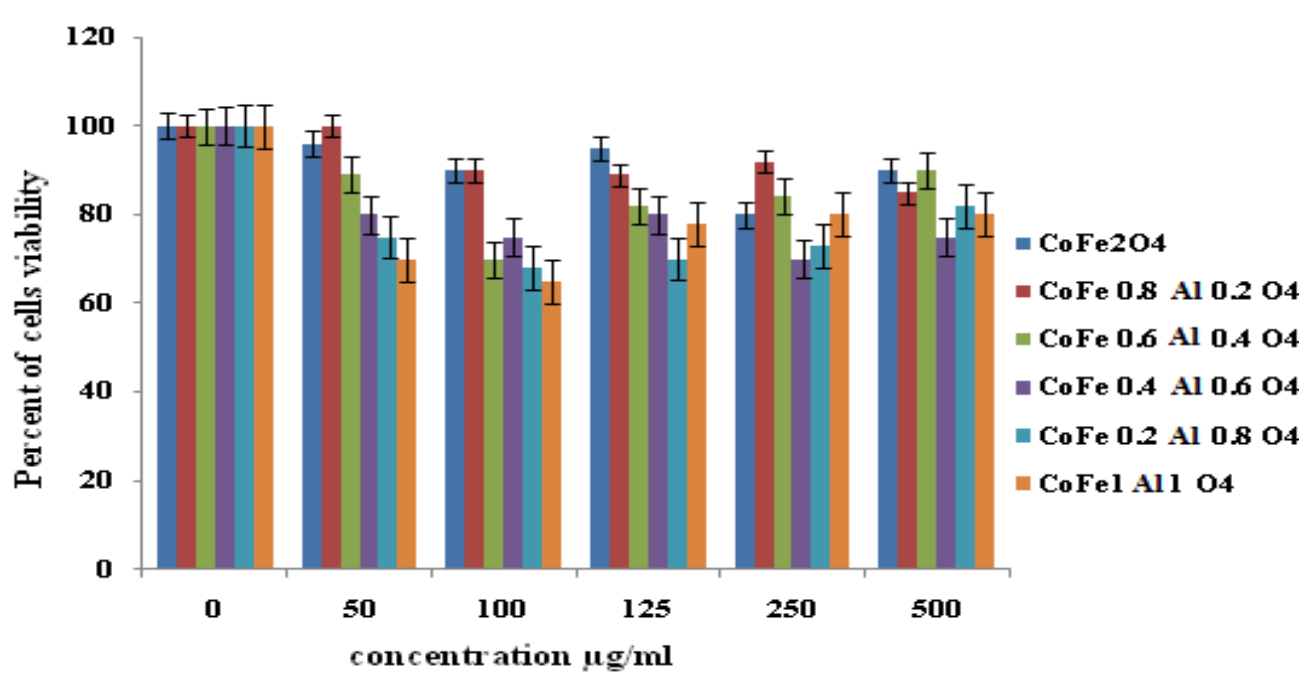

Figure 8. Percentage of cell viability with various concentrations 

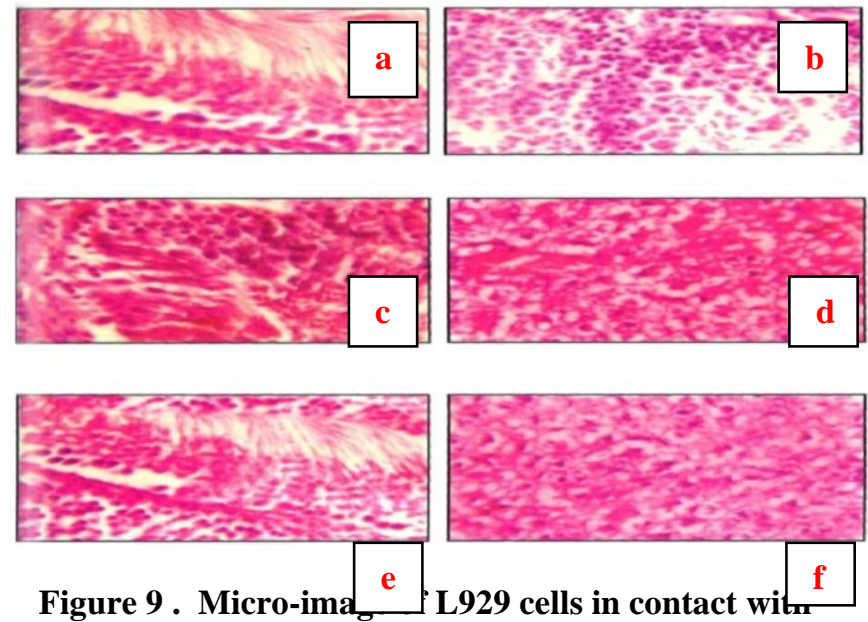

$\mathrm{CoAl}_{0.2} \mathrm{Fe}_{1.8} \mathrm{O}_{4}$ NPs.

\section{CONCLUSIONS}

The co-precipitation technique is used to produced $\mathrm{Al}$ doped and undoped nanoparticles of cobalt ferrite . XRD pattern justifies Cobalt ferrite nanoparticles as single-phase cubic spinel structure. Lattice steady and particle magnitude analysis were also done with the X-ray diffraction technique. Photoluminescence spectra denoted that the rebounding of charges in profound traps of localized external states and lattice faults. Maximum transmittance used to be acquired for $1 \% \mathrm{Al}$ doped cobalt ferrite sample. Optical band gap energy was decreased with increase in Al content. SEM images demonstrates regular particle size distribution. The increase of $\mathrm{Al}$ content that promotes coercivity and magnetization is observer through VSM study. Anticancer property of cobalt ferrite nanoparticles provides that this model might be the optimum option for biomedical utilization

\section{REFERENCES}

1. N Gupta, N., Verma, A., Kashyap, S.C. and Dube, D. (2007) 'Microstructural, dielectric and magnetic behavior of spin-deposited nanocrystalline nickel-zinc ferrite thin films for microwave applications', J. Magn. Magn. Mater., Vol. 308 pp. 137-142.

2. Adam, J., Krishnaswamy, S., Talisa, S. and Yoo, K. (1990) 'Thin-film ferrites for microwave and millimeter-wave applications', J. Magn. Magn. Mater., Vol. 83 pp.419-424.

3. Vinayak, V., Khirade, P.P., Birajdar, S.D., Alange, R. and Jadhav, K. (2015) 'Electrical and dielectrical properties of low-temperature-synthesized nanocrystalline $\mathrm{Mg}^{2+}$-substituted cobalt spinel ferrite', J SUPERCOND NOV MAGN, Vol. 28 pp.3351-3356.

4. Patil, V.G., Shirsath, S.E., More, S.D., Shukla, S.J. and Jadhav, K.M. (2009) 'Effect of zinc substitution on structural and elastic properties of cobalt ferrite', J. Alloys Compd., Vol. 488 pp.199-203.

5. Arulmurugan, R., Jeyadevan, B., Vaidyanathan, G. and Sendhilnathan, S. (2005) 'Effect of zinc substitution on Co-Zn and Mn-Zn ferrite nanoparticles prepared by co-precipitation', J. Magn. Magn. Mater., Vol. 288 pp.470-477.

6. Waje, S.B., Hashim, M., Yousoff, W.D.W. and Abbas, Z. (2010) 'Sintering temperature dependence of room temperature magnetic and dielectric properties of $\mathrm{Co}_{0.5} \mathrm{Zn}_{0.5} \mathrm{Fe}_{2} \mathrm{O}_{4}$ prepared using mechanically alloyed nanoparticles', J Magn. Magn. Mater., Vol. 322 pp.686-691.

7. Devmunde, B., Raut, A., Birajdar, S., Shukla, S., Shengule, D. and Jadhav, K. (2016) 'Structural, Electrical, Dielectric, and Magnetic Properties of Cd2', J. Nanoparticle Res.

8. Lee, J.S., Lee, B.I. and Joo, S.K. (1999) 'Effects of process parameters on structure and magnetic properties of sputtered Ni-Zn ferrite thin films', IEEE Trans. Magn., Vol. 35 pp.3415-3417.

9. Han, D., Wang, J. and Luo, H. (1994) 'Crystallite size effect on saturation magnetization of fine ferrimagnetic particles', J. Magn. Magn. Mater., Vol. 136 pp.176-182.

10. Kuo, S.Y., Chen, W.C., Lai, F.I., Cheng, C.P., Kuo, H.C., Wang, S.C. and Hsieh, W.F. (2006) 'Effects of doping concentration and annealing temperature on properties of highly-oriented Al-doped $\mathrm{ZnO}$ films', J Cryst Growth, Vol. 287 pp.78-84.

11. (2010) 'Nanoparticles by a thermal treatment method', J. Nanomater., pp.1-8.

12. Kefeni, K.K., Mamba, B.B. and Msagati, T.A. (2017) 'Application of spinel ferrite nanoparticles in water and wastewater treatment: a review.' Sep. Purif. Technol., Vol. 188 pp.399-422.

13. Singh, R. and Thirupathi, G., 'Manganese-zinc spinel ferrite nanoparticles and ferrofluids, in Magnetic Spinels-Synthesis, Properties and Applications, ed. by R. Singh, G. Thirupathi (InTech, London, 2017)', pp. 140-159.

14. Sanpo, N., Wen, C., Berndt, C.C. and Wang, J. ' Antibacterial properties of spinel ferrite nanoparticles, in Microbial Pathogens and Strate-gies for Combating Them: Science, Technology and Education, ed. by A. Méndez-Vilas (Formatex Research Centre, Badajoz, 2013)', pp. 239-250

15. Mathew, T., Malwadkar, S., Shivanand, P., Sharanappa, N. and Sebastian, C.P. (2003)' Oxidative dehydrogenation of ethylbenzene over $\mathrm{Cu}_{1-\mathrm{x}} \mathrm{Co}_{\mathrm{x}} \mathrm{Fe}_{2} \mathrm{O}_{4}$ catalyst system: influence of acid-base property'. Catal. Lett., Vol. 91 pp.217-224.

16. Peng, Y., Wang, Z., Liu, W., Zhang, H., Zuo, W., Tang, H., Chen, F. and Wang, B. (2015) 'Size-and shape-dependent peroxidase-like catalytic activity of $\mathrm{MnFe}_{2} \mathrm{O}_{4}$ nanoparticles and their applications in highly efficient colorimetric detection of target cancer cells', Dalton Trans. Vol. 44, No. 28 pp.12871-12877.

17. Mohammad Azam Ansari, Abdülhadi Baykal, Sara Asiri, Suriya Rehman. (2018)"Synthesis and Characterization of Antibacterial Activity of Spinel ChromiumSubstituted Copper Ferrite Nanoparticles for Biomedical Application", Journal of Inorganic and Organometallic Polymers and Materials,

18. Hergt, R., Dutz, S., Müller, R. and Zeisberger, M. (2006) J. Phys: Condens. Matter., Vol. 18 pp.S2919.

19. Sugimoto, M. (1999) 'The past, present, and future of ferrites', J. Am. Ceram. Soc., Vol. 82 pp.269-280

20. Pardavi-Horvath, M. (2000) 'Microwave applications of soft ferrites', J Magn Magn Mater., Vol. 215 pp.171-183.

21. Nakamura, T. (2000) 'Snoek's limit in high-frequency permeability of polycrystalline $\mathrm{Ni}-\mathrm{Zn}, \mathrm{Mg}-\mathrm{Zn}$, and $\mathrm{Ni}-\mathrm{Zn}-\mathrm{Cu}$ spinel ferrites', J. Appl. Phys., Vol. 88 pp. 348-353.

22. Jiao, Z., Wu, M., Gu, J. and Qin, Z. (2003) 'Preparation and gas-sensing characteristics of nanocrystalline spinel zinc ferrite thin films', IEEE Sens. J., Vol. 3 pp.435-438.

23. Chu, Y.Q., Fu, Z.W. and Qin, Q.Z. (2004) 'Cobalt ferrite thin films as anode material for lithium ion batteries’, Electrochim. Acta, Vol. 49 pp.4915-4921.

24. Hu, G., Choi, J., Eom, C., Harris, V. and Suzuki, Y. (2000) 'Structural tuning of the magnetic behavior in spinel-structure ferrite thin films', Phys Rev B , Vol. 62 pp.R779.

25. Wu, Z., Okuya, M. and Kaneko, S. (2001) 'Spray pyrolysis deposition of zinc ferrite films from metal nitrates solutions', Thin Solid Films, Vol. 385 pp.109-114.

26. Bhujun, B., shanmugam, A.S. and Tan, M.T. 'Aluminium-doped Nickel Copper Ferrites for high-performance Supercapacitors'.

27. Maksoud, M.I.A.A., El-Sayyad, G.S., Ashour, A.H., El-Batal A.I., Elsayed, M.A., Gobara, M., El-Khawaga A.M., Abdel-Khalek, E.K. and El-Okr M.M. (2018) 'Antibacterial, antibiofilm, and photocatalytic activities of metals-substituted spinel cobalt ferrite nanoparticles', Microb Pathog,

28. Shanmugasundaram, P. and Venkataraman, S. (2006) 'Hepatoprotective and antioxidant effects of Hygrophila auriculata K. Schum Heine Acanthaceae root extract', J Ethnopharmacol., Vol. 104, No. 1-2, pp.124-8.

29. Taimoory, S.M., Trant, J.F., Rahdar, A., Aliahmad, M., Sadeghfar, F. and Hashemzaei, N. (2017) 'Importance of the inter-electrode distance for the electrochemical synthesis of magnetite nanoparticles: synthesis, characterization, computational modelling, and cytotoxicity', J. Surf. Sci. Nanotech, Vol. 15 pp.31-39.

30. Rahdar, A., Aliahmad, M., Azizi, Y., Keikha, N., Moudi, M. and Keshavarzi, F. (2017) ' $\mathrm{CuO}$ - NiO nano composites: synthesis, characterization, and Cytotoxicity evaluation', Nanomed. Res. J, Vol. 2 pp.78-86

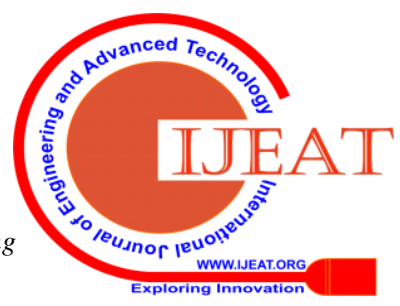


Effect Of Al3 + Inclusion on Characterization Exploration, Magnetic and Anti-Cancer Properties of Cobalt Ferrite Nanoparticles Synthesised by Co-Precipitation Process

31. Bugad, R.A., Mane, T.R., Pawar C.S. and Karche, B.R. (2013) 'structural, electrical and magnetic properties of nanoparticle size aluminium substituted cobalt ferrite', Gold. Res. Thoughts, Vol.2 No. 11.

32. Suryawanshi, S.S., Deshpande, V.V., Deshmukh, V.B., Kabur, S.M., Choudhary N.D. and Sawanta, S.R. (1999) 'XRD analysis and bulk magnetic properties of $\mathrm{Al}^{+3}$ substituted Cu-Cd ferrite', Mater. Chem. Phys, Vol. 59, No. 3, pp.199-203.

33. Gunjakar, J., More, A., Shinde, V. and Lokhande, C. (2008) 'Synthesis of nanocrystalline nickel ferrite $\left(\mathrm{NiFe}_{2} \mathrm{O}_{4}\right)$ thin films using low temperature modified chemical method', J. Alloys Compd, Vol. 465 pp.468-473.

34. Paramesh, D., Kumar, K.V. and Reddy, P.V. (2016) 'Influence of nickel addition on structural and magnetic properties of aluminium substituted $\mathrm{Ni}-\mathrm{Zn}$ ferrite nanoparticles', Processing and Application of Ceramics, Vol. 10 pp.161-167.

35. Jamila, M.T., Ahmada, J., Bukharia, S.H., Sultanb, T., Akhterc, M.Y., Ahmadd, H. and Murtaza, G. (2017) 'Effect on Structural and Optical Properties Of Zn- Substituted Cobalt Ferrite $\mathrm{CoFe}_{2} \mathrm{O}_{4}$ ', J OVONIC RES., Vol. 13, No. 1, pp.45 - 53.

36. Cai, W., Fu, C., Gao, R., Jiang, W., Deng, X. and Chen, G. (2014) 'Photovoltaic enhancement based on improvement of ferroelectric property and band gap in Ti-doped bismuth ferrite thin films', J. Alloys Compd, Vol. 617 pp.240-246.

37. Simon, J. and Andre, J.J. (2012) 'Molecular semiconductors: photoelectrical properties and solar cells', Springer Science \& Business Media.

38. Roberti, T.W., Cherepy, N. J. and Zhang, J. Z. (1998) J. Chem. Phys. Vol. 108 pp.2143.

39. Brelle, M.C. and Zhang, J.Z. (1998) J. Chem. Phys. Vol. 108 pp.3119.

40. Sengupta, A., Jiang, B., Mandal, K. C., et. al. (1999) J. Phys. Chem. B, Vol. 103 pp.3128.

41. Skinner, D.E., Colombo, D.P., Cavaleri, J. J. and Bowman, R.M. (1995) 'Femtosecond', J. Phys. Chem., Vol. 99, No. 20, pp.7853.

42. Sengupta, A., Jiang, B., Mandal, K. and Zhang, J. (1999) J. Phys. Chem. B, Vol. 103, No. 16 pp.3128.

43. Lin, Y., Zhang, J., Sargent, E.H. and Kumacheva, E. (2002) Appl. Phys. Lett., Vol. 81 pp.3134.

44. Chestoy, N., Harris, T.D., Hull, R. and Brus, L.E. (1986) J. Phys. Chem. Vol. 90 pp. 3393.

45. White, W. and DeAngelis, B. (1967) 'Interpretation of the vibrational spectra of spinels', Spectrochim. Acta A, Vol. 23 pp.985-995.

46. Wang, Z., Lazor, P. and Saxena, S. (2002) 'H.S.C. O'Neill, High pressure Raman spectroscopy of ferrite $\mathrm{MgFe}_{2} \mathrm{O}_{4}$, Mater Res Bull., Vol. 37 pp.1589-1602.

47. Chandramohan, P., Srinivasan, M., Velmurugan, S. and Narasimhan, S. (2011) 'Cation distribution and particle size effect on Raman spectrum of $\mathrm{CoFe}_{2} \mathrm{O}_{4}$ ', J. Solid State Chem., Vol. 184 pp.89-96.

48. Lawrence Kumar, Pawan Kumar and Manoranjan Kar (2013) 'Effect of non-magnetic substitution on structural and magnetic properties of spinel cobalt ferrite', J.Matter Sci: Mater Electron.

49. Mathew George, Asha Mary John, Swapna S., Nair, P.A., Joy, M.R. and Anantharaman (2006) 'Finite size effect on the structural and magnetic properties of sol-gel synthesized NiFe2O4 powders', J Magn Magn Mater., Vol. 302 pp.190-195.

50. Ramesh C.K., Maniysunder, Selvanandan S. and Anbrasan P.M. (2015) 'structural and magnetic study on al substituted MgZn mixed ferrite powder prepared by sol-gel method', Der PharmaChemica, Vol. 7, No. 5, pp.11-20.

51. Yakovlev, Y.M., Rubalikaya E.V. and Lapovok, N. (1969) 'ferromagnetic resonance in lithium ferrite', Phys. Solid State, Vol. 10 pp.2301.

52. Arakha, M., Pal, S., Samantarrai, D., Panigrahi, T.K., Mal-lick, B.C., Pramanik, K., Mallick, B. and Jha, S. (2015) 'Antimicrobial activity of iron oxide nanoparticle upon modulation of nanoparticle-bacteria interface', Sci. Rep., Vol. 5 pp.14813.

53. Haralkar, S.J., Kadam, R.H., More, S.S., Shirsath, S.E., Mane, M.L., Patil, S. and Mane, D.R. (2012) Physica B, Vol. 407 pp.4338-4346.

54. More, S.S., Kadam, R.H., Kadam, A.B., Shite, A.R., Mane, D.R. and Jadhav, K.M. (2010) J. Alloys Compds. Vol. 502 pp.477-479.

55. Padmapriya, G., Manikandan, A., Krishnasamy, V., Jagana-than, S.K. and Antony, S.A. (2016) 'Spinel $-\mathrm{N}_{\mathrm{ix}} \mathrm{Z}_{\mathrm{n} 1-\mathrm{x}} \mathrm{F}_{\mathrm{e} 2 \mathrm{O} 4}(0.0 \leq \mathrm{x} \leq 1.0)$ nano-photocatalysts: synthesis, characterization and photocatalytic degradation of methylene blue dye', J. Mol. Struct. Vol. 1119 pp.39-47.

56. Pernodet, N., Fang, X., Sun Y., et al., (2006) 'Adverse effects of citrate/gold nanoparticles on human dermal fibroblasts', Small, Vol. 2 ,
No. 6, pp. 766-773.

57. Connor, E.E. Mwamuka, J., Gole, A., Murphy, C.J. and Wyatt, M.D. (2005) 'Gold nanoparticles are taken up by human cells but do not cause acute cytotoxicity’, Small, Vol. 1, No. 3, pp. 325-327.

\section{AUTHORS PROFILE}

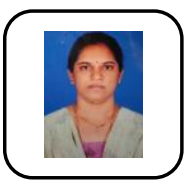

S. Sobana, M.Sc M.Phil,B.ed Research scholar in Periyar EVR college(Auto), Department of Physics, Triuchirappalli, TN, India., I am doing research in Nano-physics and their Bio-compatibility applications. Interested with Nano-materials, Drug delivery, Anti-cancer activities and also participate and presented my research work in National and International Conferences.

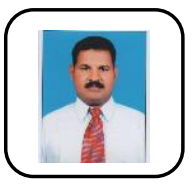

Dr. S. Alagumanian.,M.Sc.,Ph.D.,PDF,FBSS Assistant Professor (Head),PG and Research department of Botany, H.H The Rajah's college(Auto),Pudukkottai..TN, India He is doing research in Nano-Biotechnology, Plant Tissue culture. He Guidance render of Ph.D ongoing 3 students in Nano-Biotechnology and Pharmacognosy and completed 8 students in the field of Biotechnology. He has organized 3 international and 5 National conferences and also published around 15 papers in well reputated Journals. He has visited 7 countries and awarded 3 major and 5 minor projects. He has presented his Research work around 80 National conference and 20 International conferences. Research interested with Nano particle and Drug Delivery, Bio-molecule diagnosis and Reviewer of Elsevier journal.

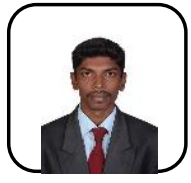

Dr.R.Dinesh Kumar.,M.E.,MBA.,Ph.D, Faculty, Department of Mechanical Engineering, NIT Goa, India. $\mathrm{He}$ is doing research in Friction Stir Welding in collaboration with ISRO He has organized 1 National conferences and also published around 7 papers SCI/SCOPUS Journals. He has presented his Research work around 10 International conferences. He holds a book chapter in Metal Additive Manufacturing and also applied for a patent in FSW Research. Apart from that he is also carrying out research in bio medical implants using Addititve Manufacturing.

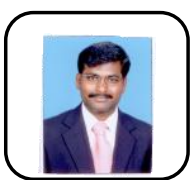

Dr. P. Shakkthivel., M.Sc.,Ph.D.,PDF, Professor, department of Nano-science and Technology, Alagappa University,Karaikudi,TN, India. He is doing research in Nano-technology,Earned in Electrochemistry from Alagappa university. He Guidance render of Ph.D ongoing 4 students in Nano-technology and completed 5 students. He has organized 10 international and 20 National conferences and also published around 53 papers in well reputated Journals. He has visited 9 countries and awarded 7 major and 5 minor projects. He has presented his Research work around 80 National conference and 20 International conferences. Research interested with Nano particle and Drug Delivery, Bio-molecule diagnosis and Reviewer of ACS,RSC and Elsevier journal.

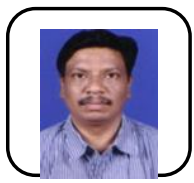

Dr. P. Sivakumar., M.Sc.,M.Phil,Ph.D.,Associate Professor, department of Physics,Periayr EVR college,trichy, TN, India. $\mathrm{He}$ is doing research in Nano-Physics and Polymer hased electrolytes in Lithium battery applications,Fuel cells,Spectroscopy techniques. He Guidance render of Ph.D ongoing 4 students in Nano-technology and completed 2 students. He has organized 5 international and 10 National conferences and also published around 23 papers in well reputated Journals. He has visited 2 countries and awarded 1 major and 3 minor projects. He has presented his Research work around 30 National conference and 20 International conferences. Research interested with Nano-physics,Lithium Ion batteries and Drug Delivery, Reviewer of Elsevier journal. 